ROCZNIKI NAUK PRAWNYCH

Tom XXX, numer $2-2020$

DOI: https://doi.org/10.18290/rnp20302-3

DARIUSZ MAKIŁŁA

\title{
GROCJUSZOWSKA SYSTEMATYKA PRAWA
}

Dylemat pojawiający się nieraz przy ocenie dorobku Hugona Grocjusza (1583-1645), sprowadzający się do pytania, kim w rzeczywistości był holenderski myśliciel: filozofem, prawnikiem, historykiem czy teologiem - wydaje się nie do końca możliwy do rozstrzygnięcia. Ocena bowiem dzieła Grocjusza zależna bywa $\mathrm{z}$ reguły od punktu widzenia tego, kto będzie jej dokonywał, a zwłaszcza podejścia do tej wybranej części nauki słynnego Holendra, która zostanie poddana ocenie. Grocjusz przekraczał bowiem w swoich poszukiwaniach różne granice przedmiotowe, przenikając i łącząc wątki o różnej treści, które nadały jego koncepcjom szczególnego wyrazu i znaczenia. Jako filozof Grocjusz zaliczany był do współtwórców kierunku filozoficznego o szczególnym w wiekach XVI-XVIII znaczeniu dla nauki prawa oraz umysłowości tego okresu, jakim była szkoła prawa natury. Z kolei jako teolog stawiał pytania o sposoby, ale też zasady postępowania w kwestiach wiary. Od lat uznaje się go również niezmiennie - co jest poglądem szczególnie rozpowszechnionym, ale jednocześnie, jak należy uznać, zawężającym możliwości i znaczenie jego nauki do czysto utylitarnego ujęcia - za „ojca nauki prawa międzynarodowego", której najbardziej znaną ekspozycją było wydane w 1625 r., podczas pobytu myśliciela na wygnaniu w Paryżu, trzytomowe dzieło De iure belli ac pacis ${ }^{1}$.

Ale właśnie to dzieło, aczkolwiek istotnie formułujące w czasach nowożytnych zasady postępowania między narodami w warunkach pokoju i wojny, które przyniosło Grocjuszowi trwały rozgłos i miejsce w dziejach nauki,

Dr hab. DARIUSZ MAKIŁŁA, prof. nadzw. - Instytut Nauk Prawnych Akademii Ekonomiczno-Humanistycznej w Warszawie, ul. Okopowa 59, 01-043 Warszawa; e-mail: d.makilla@vizja.pl; ORCID: https://orcid.org/0000-0003-0775-4617

${ }^{1} \mathrm{H}$. Grotius, De iure belli ac pacis libri tres. In quibus ius naturae \& Gentium: item iuris publici praecipua explicantur, Parisiis 1625. 
zawierało jednocześnie ideę czegoś, co wydaje się, że było dla niego być może równie istotne, chociaż podlegające $\mathrm{w}$ trakcie jego działalności ewolucji, a mianowicie koncepcję pewnego systemu prawnego, mającego w swoim wyrazie określone przeznaczenie.

Uwaga ta jest o tyle istotna, że dzieła Grocjusza nie można rozpatrywać $\mathrm{w}$ oderwaniu od tego, co w ogóle rozumiał pod pojęciem prawa, ale również w jaki sposób postrzegał jego funkcje. Nie można bowiem zapominać, że zasadniczym celem Grocjusza, sprecyzowanym zresztą we wstępie do wspomnianego już De iure belli ac pacis, było - jak to sam określał - prawoznawstwo (iurisprudentia) ${ }^{2}$. Pojmował przy tym prawoznawstwo jako stworzenie systemu prawa, który - jak sam twierdził, o czym dzisiaj wiemy, że czynił tak poniekąd przesadnie i na wyrost - nigdy przed nim nie został przez nikogo przedstawiony w sposób całościowy ${ }^{3}$.

Ważne natomiast jest, że system prawa stworzony przez niego, uznawany wprawdzie jeszcze za niepełny i niedoskonały, zwłaszcza w zakresie precyzyjności wykładu ${ }^{4}$, miał jednak w założeniu holenderskiego myśliciela wyraźnie funkcjonalne przeznaczenie. Nie był on przewidziany do bezpośredniego stosowania w dydaktyce czy też w praktyce jurydycznej, co najczęściej bywało celem ówczesnych dzieł z zakresu systematyzacji prawa ${ }^{5}$. System ten był natomiast bardziej nieodzowną częścią poglądów Grocjusza zawartych w traktacie, którego nośność nie zamykała się tylko w kręgu nauki prawa międzynarodowego czy też nawet szeroko pojmowanej filozofii prawa. Systematyka prawa miała jednak w jego ujęciu także znaczenie praktyczne.

${ }^{2} \mathrm{H}$. Grotius, De iure belli ac pacis libri tres. In quibus ius naturae \& Gentium, item juris publici praecipua explicantur, Amsterdam 1646, Liber I, Caput 1.10 [dalej: IBP, I, 1.10].

${ }^{3}$ Artis formam ei imponere multi ante hac definarunt: perfecit nemo. H. GROTIUS, De iure belli ac pacis libritres. In quibus ius naturae \& Gentium, item juris publici praecipua explicantur, Amsterdam 1646 [dalej: IBP, Proleg. 1, 30].

${ }^{4}$ F. WIEACKER, Privatrechtsgeschichte der Neuzeit unter besonderer Berücksichtigung der deutschen Entwicklung, Göttingen: Vandenhoeck \& Ruprecht 1952, s. 168.

${ }^{5}$ E. HolthöFer, Die Literatur zum gemeinen und partikularen Recht in Italien, Frankreich, Spanien und Portugal, [w:] Handbuch der Quellen und Literatur der neuren europäischen Privatrechtsgeschichte, Bd. 2, Tlbd. 3, Hrsg. H. Coing, München: C.H. Beck 1977, s. 103 n.; A. SöLLNER, Die Literatur zum gemeinen und partikularen Recht in Deutschland, Österreich, Niederlanden und der Schweiz, [w:] Handbuch der Quellen und Literatur, Bd. 2, Tlbd. 3, s. 501 n.; O. GIERKE, Johannes Althusius und die Entwicklung der naturrechtlichen Staatstheorien, Breslau: Verlag M. und H. Marens 1902, s. 37-56; P.-J. WINTERS, Die „Politik“ des Johannes Althusius und ihre zeitgenössischen Quellen. Zur Grundlegung der politischen Wissenschaft im 16. und im beginnenden 17. Jahrhundert, Freiburg im Breisgau: Verlag Rombach 1963, s. 138-169; H.J. vAN EIKEMA HOMMES, Naturrecht und positives Recht bei Johannes Althusius, [w:] Politische Theorie des Johannes Althusius, Hrsg. K.-W. Dahm, W. Krawietz, D. Wyduckel, Berlin: Duncker \& Humblot 1988, s. 371-390. 
Stanowiła ona bowiem konstrukcję istniejącego i funkcjonującego w stosunkach społecznych ładu prawnego, o którym wiedza, odzwierciedlając pewien naturalny porządek, nie była tylko przedmiotem nauczania, ale stanowiłaby istotny element świadomości ludzi stosujących się do niego. W takim też podejściu do prawa i porządku prawnego Grocjusz upatrywał zasadnicze przeznaczenie swojego przedsięwzięcia.

Stawiając sobie za cel stworzenie systematyki prawa, jako własnego wkładu w całokształt nauki prawa, pozostającej - o czym Grocjusz jednoznacznie i często stwierdzał - w opozycji do dotychczasowych rozwiązań w tym zakresie, do których nawiązywał w swych licznych komentarzach ${ }^{6}$, omówienie swojej systematyki rozpoczynał od sprecyzowania pojęcia, a jednocześnie określenia miejsca i roli prawa w całości porządku społecznego. Ład społeczny, jaki istniał w tym porządku, był bowiem zdeterminowany funkcją prawa, gwarantującą nie tylko jego zastosowanie, ale przede wszystkim zachowanie. Uznawał bowiem Grocjusz, że prawo nie oznacza niczego innego, jak tylko to, co jest sprawiedliwe, a więc - jak konstatował - prawem jest tylko to, co nie jest sprzeczne ze sprawiedliwością. Niesprawiedliwe zaś jest natomiast to, co pozostaje w sprzeczności z naturą społeczeństwa złożonego $\mathrm{z}$ istot rozumnych ${ }^{7}$. Podążając tą myślą, $\mathrm{w}$ której pojęcie sprawiedliwości, jak się okazywało, odgrywało rozstrzygającą rolę, Grocjusz formułował pogląd o istnieniu dwóch rodzajów prawa, które znajdowały oparcie w podstawowej dla rozumienia pojęcia sprawiedliwości, poniekąd je determinującą, zasadzie równości $\mathrm{w}$ stosunkach między ludźmi żyjącymi na tym samym poziomie, a więc prawa stosunków równości (ius aquatorium) i prawa stosunków władzy, występującymi między rządzącym a rządzonym (ius rectorium $)^{8}$. Grocjusz był jednak również świadomy tego, że prawo można określać także w inny sposób, stosując odmienne kryteria, dokonując jego zdefiniowania $\mathrm{z}$ innych pozycji, jak też precyzować je w odniesieniu do innej sytuacji. Tak formułując pogląd na prawo, wskazywał na wynikające $z$ tego inne jeszcze możliwości określenia prawa według odrębnych kryteriów. Przede

\footnotetext{
${ }^{6}$ R. TucK, Grotius, Carneades and Hobbes, "Grotiana" 4 (1983), s. 43-62.

${ }^{7} \mathrm{Nam}$ ius hic nihil aliud quam quod justum est significat: idque negante magis sensu, quam ajente, ut jus sit quod iniustum non est. Est autem iniustum, quod naturae societatis ratione utentium repugnat. I, 1, III

${ }^{8}$ Sicut autem societas alia est fine inaequilitate, ut Inter fratrem, cives, amicos, faederatos: alia inaequalis, ut Inter patrem \& liberos, dominus \& serum, regem \& subditos, Deum \& homines: ita iustum aliud est aequo inter se viventium, aliud eius qui regit $\&$ qui regitur, qua tales sunt: quorum hoc ius Rectorium, illud Aequatorium recte. IBP, I, 1, III
} 
wszystkim wskazywał na możliwość oznaczenia prawa jako kwalifikacji moralnej osoby $\mathrm{w}$ przedmiocie posiadania czegoś lub działania zgodne ze sprawiedliwością ${ }^{9}$. Z tego kryterium mógł wynikać - jego zdaniem - podział prawa, odpowiadający sprawiedliwości w ścisłym znaczeniu (facultas) ${ }^{10}$ oraz sprawiedliwości rozdzielającej, przynoszącej pożytek innym ludziom (iustitia attributrix $)^{11}$. Jako trzecie znaczenie prawa - dość rozpowszechnione w obiegu - przywoływał - niejako porządkowo - pojęcie prawa (ius), które uznawał za to samo co przepis prawny (lex), traktując je za regułę czynności moralnych zobowiązujących do postępowania w sposób prawny (rectum $)^{12}$.

Wskazując na te rozwiązania, pokazujące różne możliwości określenia prawa, a także wynikających z nich podziałów, za najlepszy Grocjusz uznawał jednak znany i wywodzący się jeszcze od Arystotelesa podział na prawo naturalne (ius naturale) i prawo pozytywne (ius voluntarium), przy czym podział ten, mający pozornie dychotomiczny charakter, oparty był jednak w jego rozumieniu - nie tylko na powiązaniach poziomych, co mogłoby wynikać $\mathrm{z}$ ich równoczesnego zestawienia, ale również pionowym, a w zasadzie przede wszystkim na ujęciu prawa w oryginalnym, hierarchicznym porządku, będącym wyraźną systematyką.

W tym układzie, w którym zasadniczym czynnikiem byłaby rozległość istnienia i stosowania, a bardziej nawet obowiązywania prawa, jeśli można byłoby odnieść to pojęcie to pewnej filozoficznej koncepcji prawa, prawem najszerszym było ius naturale. Znajdowało się ono najwyżej i wypełniało wszechobecnie cały porządek zarówno prawny, jak i - co miało dla Grocjusza fundamentalne znaczenie - społeczny, niezależnie od stopnia i poziomu, jak też

\footnotetext{
${ }^{9}$ Qualitas moralis personae, competens ad aliquid iuste habendum vel agendum. Personae competit hoc ius, etiamsi rem interdum sequatur, ut servitudes praediorum quae iura realia dicuntur comparatione facta ad alia mere personalia: non quia non ipsa quoque personae competent, sed quia non alii competent quam qui rem certam habeat. Qualitas autem moralis perfecta, Facultas nobis dicitur; minus perfecta, Aptitud: quibus respondent in naturalibus, illi quidem actus, juic autem publicae quisque ad usus publicos magis obligatur quam creditori. IBP, I, 1, 4.

${ }^{10}$ Nos posthac ius proprie aut stricte dictum appellabimus: sub qui continentur Potestas, tum in se, quae libertas dicitur, tum in alios, ut patria, dominica: Dominium, plenum sive minus pleno, ut ususfructus, ius pignoris: \& creditum, cui ex adverso respondet debitum. IBP, I, 1, 5.

${ }^{11}$ Comes earum virtutum quae aliis hominibus utilitatem adferunt, ut liberalitatis, misericordiae, providentiae rectricis. IBP, I, 1,8 .

${ }^{12}$ Est \& tertia iuris signification quae idem valet quod Lex, quities vox legis largissime sumitur, ut sit regula actuum moralium obligans ad id quod rectum est. (...). Diximus autem, ad rectum obligans, non simpliciter ad iustum, quia ius hac notione, non ad solius iustitiae, qualem exposuimus, sed \& aiarum virtutum materiam pertinent. Attamen ab hoc iure, quod rectum est, laxius iustum dicitur. IBP, I, 1, 9.
} 
form jego organizacji, a ponadto bez względu na jakiekolwiek zróżnicowania, jakie między ludźmi, czy też $\mathrm{w}$ ich sposobach organizacji można byłoby znaleźć i wykazać.

Przekonanie o nadrzędnym charakterze zasad prawa natury otwierało Grocjuszowi drogę do ustalenia wzajemnych zależności oraz podstaw zdefiniowania prawa natury, jako regulatora porządku społecznego, z innymi prawami. Tym bowiem, co wyróżniało jego systematykę od innych tego rodzaju prób czynionych wówczas w nauce prawa, było konsekwentne odwoływanie się w niej nie tyle do norm prawnych - te bowiem pozostawiał prawom pozytywnym, właściwym bardziej - jak to sam określał - prawom ludzkim, zamykającym się w kręgu pojęcia leges, odpowiedniego każdemu społeczeństwu ${ }^{13}$, a jednocześnie nie tak rozległym, jak prawo natury i tym samym znajdującym się od niego hierarchicznie niżej w Grocjuszowskiej systematyce prawa. Przede wszystkim jednak, wskazując na ius naturale, budował swój system prawa na regułach i zasadach, na których opierało się funkcjonowanie ogólnego porządku społecznego, powstałego wskutek, jak to określał, appetitus societatis, czyli popędu do życia wspólnie z innymi ludźmi, w sposób pokojowy i zorganizowany odpowiednio do właściwości ludzkiego umysłu ${ }^{14}$. Życie społeczne oparte na poznawaniu i działaniu przez ludzi jako członków wspólnoty, według ogólnych wskazań, zgodnych z naturą ludzką ${ }^{15}$, miało na celu przede wszystkim troskę o zachowanie społeczeństwa. Stan ten odpowiadał umysłowi człowieka, będąc tym samym źródłem prawa natury ${ }^{16}$, jako prawa właściwego dla ludzkiej natury ${ }^{17}$.

Treść jednakże prawa natury sprowadzona została, w przekonaniu Grocjusza, do zasad prawnych o najbardziej zasadniczym znaczeniu, wspólnych

\footnotetext{
${ }^{13}$ Iuris ita accepti optima partitio est (...), ut sit aliud ius naturale, aliud voluntarium, quod ille legitimum vocat. IBP, I, 1, 9.

${ }^{14}$ Inter haec autem quae homini sunt propria, est appetites societatis, id est communitatis, non qualiscunque, sed tranquillae, \& pro sui intellectus modo ordinatae. IBP, Proleg. 6.

${ }^{15}$ Inesse etiam facultatem sciendi agendique, secundum generalia praecepta, par est intelligi, cui qui conveniunt ea iam sunt non omnium quidem animantium, sed humanae naturae congruentia. IBP, Proleg. 7.

${ }^{16}$ Haec vero, quam rudi modo iam expressimus, humano intellectui conveniens, sons est eius iuris, quod proprie tali nomine appellatur. IBP, Proleg. 8.

${ }^{17}$ Qui enim homo supra caeteras animantes non tantum vim obtinet socialem de qua diximus, sed $\&$ judicium ad aestimandaquae delectant aut nocent, non praesentia tantum, sed $\&$ future, \& que in utrumvis possunt ducere; pro humani intellectus modo etiam in his iudicium recte conformatum sequi, neque metu, aut voluptatis praesentis illecebra corrumpi, aut temerario rapi impetus, conveniens esse humanae naturae; \& quod tali iudicio plane repugnant, etiam contra ius naturae, humane scilicet, esse intelligitur. IBP, Proleg. 9.
} 
dla różnych narodów, religii i kultur. Co więcej, według niego nadrzędny porządek, jaki stanowiło prawo natury, był niezmienny i nienaruszalny. Nawet Bóg - jak twierdził - nie mógł dokonać jego zmiany ${ }^{18}$. Tym bowiem, co tworzyło instynkt życia społecznego, były właśnie reguły prawa natury, znajdujące swoje odzwierciedlenie w rozumie ludzkim, jako nakaz prawego rozumu. Wskazywał on - zdaniem Grocjusza - na istnienie w każdej czynności, zależnie od jej zgodności lub niezgodności z rozumną naturą człowieka niezbędną z woli Boga konieczność ich zachowania i posługiwania się nimi, bądź czynienia inaczej, jeśli zostały one przez Boga zabronione ${ }^{19}$. Za zgodne $\mathrm{z}$ prawem natury uważa się również rzeczy niepozostające $\mathrm{z}$ nim $\mathrm{w}$ sprzeczności bądź te, które rozum wskazuje jako regułę uczciwości lub regułę postępowania lepszą od jej przeciwieństw, chociaż niebędące zobowiązaniem o charakterze prawnym ${ }^{20}$. Grocjusz także podkreślał, że prawo naturalne zajmuje się nie tylko rzeczami istniejącymi niezależnie od woli ludzkiej, ale także wieloma innymi, będącymi właśnie następstwem działania woli ludzkiej, co pokazywał na przykładzie własności, która po jej wprowadzeniu tworzyła prawo naturalne, zakazujące jej zabierania wbrew woli właściciela ${ }^{21}$.

Nakazy prawa natury determinowały więc - w rozumieniu Grocjusza życie społeczne ${ }^{22}$. O powstaniu i istnieniu ludzkich relacji pozwalających na funkcjonowanie społeczeństwa, państw i narodów, ale decydujących także o potrzebie zachowania pośród nich odpowiednich zasad postępowania rozstrzygały rozum i stanowiąca jego wyraz świadoma wola ludzi ${ }^{23}$, oparta na

\footnotetext{
${ }^{18}$ Est autem ius naturale ad eo immutabile, ut nea Deo quidem mutari queat. IBP, I, 1.10).

${ }^{19}$ Ius naturale est dictatum rectae rationis indicans, ac tui alicui ex eius convenentia aut disconvenentia cum ipsa natura rationali, inesse morale turpitudinem aut necessitate moralem, ac consequenter ab auctore naturae Deo talem actum aut vetari aut praecipi . Actus de quibus tale extat dictatum, debiti sunt aut illicit per se atque ideo a Deo necessario praecepti aut vetiti intelliguntur. IBP, I, 1, 10; R. TUCK, Philosophy and Government 1572-1651, Cambridge: Cambridge University Press 1993, s. 197-198.

${ }^{20}$ Ad iuris autem naturalis intellectum, notandum est quedam dicit eius iuris non proprie (...) ea que ratio honesta aut oppositis meliora esse indicat, etsi non debita, solent dici iuris naturalis. IBP, I, 1, 10.

${ }^{21}$ Sciendum praeterea, ius naturale non de iis tantum agree quae citra voluntatem humanam existent, sed de multis etiam quae voluntatis humanae actum consequuntur. Sic dominium, quale nunc in usu est, volintas humana introduxit: at eo introducto nefas mihi esse id arripere te invite quiod tuy est dominii ipsum indicat ius natural, quare furtum naturali iure prohibitum dixit. IBP, I, 1,10. P. HagGenmacher, Droits subjectifs et système juridique chez Grotius, [w:] Politique, droit et théologie chez Bodin, Grotius et Hobbes, Préface de Yves Charles Zarka, Paris: Éditions Kimé 1997, s. 73-78.

${ }^{22}$ K. HAAKOnSSEN, The Moral Conservatism of Natural Rights, [w:] Natural Law and Civil Sovereignty. Moral Right and State Authority in Early Modern Political Thought, ed. I. Hunter, D. Saunders, Houndmills: Palgrave Macmillan 2002, s. 28-33.

${ }^{23}$ K. HaAkonssen, Natural Law and Moral Philosophy: From Grotius to the Scottish Enlightenment, Cambridge: Cambridge University Press 1996, s. 322-341.
} 
elementarnych zasadach postępowania, będących - jak stwierdzał holenderski myśliciel - wynikiem naturalnego dążenia do realizacji potrzeb człowieka, albowiem w przeciwnym razie naturalny ład społeczny, oparty na wzajemnych międzyludzkich stosunkach, przestałby istnieć. Katalog tych zasad był zresztą $w$ jego rozumieniu nie tylko enumeratywny, ale w swej treści, a także przeznaczeniu, którego można się domyślać, niezwykle wymowny. Należały do nich zasada powstrzymywania się od tego, co jest własnością innych, dokonanie zwrotu, jeśli mamy coś cudzego, wraz z zyskiem, jaki osiągnęliśmy, konieczność naprawienia szkody wyrządzonej z własnej winy oraz uznanie, że pomiędzy ludźmi pewne czyny zasługują na karę, a nade wszystko obowiązek dotrzymywania przyrzeczen ${ }^{24}$. Podstawowe znaczenie pośród zasad prawa natury, jako kategoria rozumowo stwierdzona i wyznaczona takimi czynnikami, jak wola i świadomość, znajdowała zasada dotrzymywania zobowiązań.

System praw Grocjusza, mający swoją hierarchię, oparty na pionowym porządku, wyznaczony był właśnie zasadami prawa natury, rzutującymi na relacje między poszczególnymi prawami. W tym układzie prawo natury ludzkiej współistniało z boskim prawem naturalnym, jako część porządku wynikającego z woli boskiej, któremu ludzie powinni się poddać, jak to nakazuje ludzki rozum w sposób niedopuszczający sprzeciwu, albowiem Bóg chciał - jak stwierdzał to Grocjusz - by zasady prawa natury w ludziach istniały ${ }^{25}$. Prawa te uczynił Bóg za pomocą wydanych przez siebie praw jasnymi, aby były one zrozumiałe dla wszystkich, rozciągając nad skłonnościami ludzkimi ścisłą kontrolę, a zarazem zakreślając im pewne ramy i granice ${ }^{26}$.

Znacznie bardziej praktycznie rozbudowane o kilka stopni było w systematyce Grocjusza prawo pozytywne. Hierarchicznie niżej usytuowane od prawa naturalnego, było nie tylko zróżnicowane swoją treścią oraz formą,

\footnotetext{
${ }^{24}$ Quo pertinent alieni abstinentia, \& si quid alieni habeamus, aut lucre inde fecerimus restitutio, promissorum implendorum obligatio, damni culpa dati reperatio, $\&$ et poena inter homines meritum. IBP, Proleg. 8.

${ }^{25}$ Et haec jam alia iuris origo Est praeter illam naturalem, veniens scilicet ex libera Dei voluntate, cui nos subiici debere intellectus ipse noster nobis irrefragabiliter dictat. Sed \& illud ipsum de quo egimus natural ius, sive illud sociale, sive quod laxius ita dicitur, quamquam ex principiis homini nternis prostuit. Deo tamen ascribi merito potest, quia ut talia principia in nobis existerent ipse voluit. IBP, Proleg. 12; zob. J. ZAJADŁO, Hugo Grocjusz i hipoteza etiamsi daremus, non esse Deum, „Czasopismo Prawno-Historyczne” 58 (2006), z. 1, s. 208-209.

${ }^{26}$ Illa quoque ipsa principia Deus datis legibus magis conspicua fecit, etiam iis quibus imbecillior est ad ratiocinandum vis animi: $\&$ in diversa trahentes impetus, qui nobis ipsis, quique aliis consulunt, vagary vetuit, illos, quippe vehementiores, addictius regens $\&$ fine ac modo coercens. IBP, Proleg. 13.
} 
ale równocześnie występujące na rozłożonych pionowo poziomach, pozostających z sobą w określonych zależnościach, które podobnie jak ludzkie prawo naturalne, ale jednak inaczej, brało swój początek z czyjejś woli, dzieląc się również na pozytywne prawo ludzkie oraz boskie ${ }^{27}$. Ujmując z kolei sprawę systemowo, Grocjusz wskazywał na trzy rodzaje prawa ludzkiego: prawo cywilne, prawo o szerszym zakresie i prawo o węższym zakresie niż prawo cywilne ${ }^{28}$.

Prawem pozytywnym, które Grocjusz wyróżniał w swojej systematyce, będące jednak ze względu na swój zasięg najbardziej rozległe, czyli prawem pozytywnym o szerszym zakresie, jak je nazywał - chociaż w skali całej ludzkości niekoniecznie jednolitym, albowiem możliwe było, co podkreślał autor De iure belli ac pacis, aby w różnych częściach świata opierało się ono na odmiennych od siebie podstawach - było prawo narodów ${ }^{29}$. Powstało ono w stosunkach między wszystkimi państwami bądź znacznej ich części, mając na względzie pożytek nie pojedynczych społeczności (coetus), ale pożytek powszechności (universitas) ${ }^{30}$. Czerpie ono - zdaniem holenderskiego myśliciela - swoją moc obowiązującą z umowy wynikającej z woli narodów lub ze zwyczaju, uznawanego przez Grocjusza za milczącą umowę (pactum tacitum), dowodzonego także nieprzerwaną praktyką i świadectwem biegłych ${ }^{31}$.

Prawem, które Grocjusz sprecyzował dla pełnego ustalenia relacji społecznych, jako ich funkcjonalny instrument, wyrażający społeczne potrzeby oraz uwarunkowania, a także wynikające z prawa natury zasady postępowania, były normy prawa cywilnego. Prawo cywilne, jako ludzkie prawo pozytywne (ius voluntarium) - podobnie jak prawo natury - wynikało również z czyjejś woli, niemniej i ta wola miała swoje zakotwiczenie oraz oparcie w zasadach prawa natury, będącego nakazem prawego rozumu, który w zgodzie $\mathrm{z}$ nim zabrania lub nakazuje dokonanie poszczególnych czynności ${ }^{32}$.

${ }^{27}$ Alteram juris speciem esse diximus jus voluntarium, quo ex voluntate originem ducit: estque vel humanum vel divinum. IBP, I, 1.13

${ }^{28}$ Est ergo hoc vel civile, vel latius patens, vel arctius. IBP, I, 1, 14.

${ }^{29}$ P. Haggenmacher, Genèse et signfication du koncept de ,ius gentium” chez Grotius', „Grotiana” 2 (1981), s. 44-102, appendices s. 631-643.

${ }^{30}$ Sed sicut cuiusque civitatis iura utilitatem suae civitatis respiciunt, ita inter civitates aut omnes aut plerasque ex consensu iura quedam nasci potuerunt, \& et nata apparet, quae utilitatem resciperent non coetuum singulorum, sed magnae illius universitatis. Ed hoc ius est quo gentium dicitur, quoties in nomen a iure naturali distinguimus. IBP, Prolog. Prolog. 17.

${ }^{31}$ Probatur autem hoc ius gentium (....) usu continuo \& testimonio peritorum. IBP, I, 1, 14.

${ }^{32}$ Ius naturale est dicta tum rectae rationis indicans, actus alicui, ex jus convenientia aut disconvenentia cum ipsa natura rationali, in esse morale turpitudinem aut necessitate moralem, ac consequenter ab auctore naturae Deo talem actus aut vetami aut praecipi. IBP, I, 1,10. 
Prawo cywilne nie miało charakteru zasad niezmiennych, jak prawo natury, ale pochodziło ono w koncepcji Grocjusza od władzy cywilnej, rządzącej państwem, stanowiącym doskonały związek (coetus) ludzi wolnych, którzy zjednoczyli się w celu korzystania z prawa i dla wspólnego dobra ${ }^{33}$. Przyłączenie się do jakiejś społeczności albo poddanie się władzy prowadzi do zaciągnięcia zobowiązania w sposób wyraźny lub też oznacza - co może wynikać z natury czynności prawnej - iż przyłączający się do społeczności zobowiązali się w sposób milczący, że stosować się będą do tego, co postanowiła większość społeczności albo co uznali ci, którym oddano władzę ${ }^{34}$. Matką prawa cywilnego - jak to określał Grocjusz - jest zobowiązanie, będące wynikiem zgody człowieka, ale jednocześnie czerpiące jednak swoją moc $\mathrm{z}$ prawa naturalnego ${ }^{35}$.

Tym samym więc prawo cywilne mogło być nie tylko uszczegółowieniem prawa naturalnego, ale mogło się od niego różnić, jak też mogło być w ogóle zmienne. Fundamentem prawa cywilnego, jak zostało to już określone, było jednak przede wszystkim dochowywanie zobowiązań, stanowiące, według Grocjusza, zasadę postępowania, którego podstawą jest stosowanie się do reguł prawa natury, mającego przecież nadrzędny poziom. Głównym jednakże problemem wynikającym z nauki Grocjusza, a dotyczącym zasady dotrzymywania zobowiązań, było nie tylko sprecyzowanie treści oraz istoty tej zasady, zaprezentowanej u niego poprzez najróżniejsze jej odmiany i warianty zachowań, ale także działania pokazujące przejawy ich stosowania w stosunkach prawnych obowiązujących w relacjach społecznych. Te z kolei, w sposób ścisły wynikając z zobowiązań, wypływały - jak wskazywał Grocjusz - ze związanej z prawem natury zasady dotrzymywania umów, albowiem - jak podkreślał - umowy oparte są na wzajemnym zobowiązaniu się przez ludzi ${ }^{36}$. Przede wszystkim jednak istotne było określenie funkcji tej zasady w całości

\footnotetext{
${ }^{33}$ Civile est quod a potestare civili proficiscitur. Potestas civilis est quae civitat ipraest. Est autem civitas coitus perfectum liberorum hominum, juris fruendi \& communis utilitatis causa sociatus. Ius arctiu sparens $\&$ ab ipsa potestate civili non veniens, quanquam ei subditum, varium est, praecepta patria, dominica; \& si qua sunt similia in se continens. IBP, I, 1, 14.

${ }^{34} \mathrm{Nam}$ qui se coetui alicui aggregaverant, aut homini ho minibusie subjecerant, hi aut expresse promiserant, aut ex negotii natura facie promississe debebant interligi; secuturos se id quo aut coitus pars major, aut hi qui bus delata potestas erat constituissent. IBP, Proleg. 15.

${ }^{35} \mathrm{Nam}$ naturalis iuris mater ipsa humana natura, quae nos etiamsi re nulla indigeremus ad societatem mutuam appendam ferrer: Civilis vero iuris mater est ipsa ex consensu obligatio, que cum ex naturali jure vim suam habeat, potest natura hujus quoque juris quasi proavia divi. IBP, Proleg. 16.

${ }^{36}$ Deinde vero cum juris naturae sit stare pactis, (necessarius enim erat inter homines aliquis se obligandi modus fingi potest,) ab hoc ipso fonte iura civilia fluxerunt. IBP, Proleg. 15.
} 
poglądów Grocjusza, dotyczących prawa oraz porządku społecznego, odnoszącego się zarówno do stosunków osobowych, jak i publicznych. Normy prawa cywilnego określały więc bardziej dokładnie wykonywanie zasady dotrzymywania zobowiązań. Przez swoją powszechność, ale również szczegółowość zastosowania, a także występowania w różnych sytuacjach i wariantach pokazywały one jednocześnie jej uniwersalność.

$\mathrm{Na}$ dole swej systematyki prawa, niżej jeszcze w jej hierarchii od prawa cywilnego, ale należącym do prawa ludzkiego pozytywnego, umiejscawiał Grocjusz prawo cywilne, jak to określił, o węższym zakresie, będące regułami postępowania w środowiskach podlegających wprawdzie władzy cywilnej, ale niepochodzącej od niej, a polegającej na wydawaniu nakazów np. w rodzinach ${ }^{37}$.

Systematyka praw Grocjusza zawierała jeszcze jedną kategorię praw pozytywnych, różniących się oczywiście od prawa natury, ale jednocześnie stanowiących część odrębną oraz podlegających w systematyce praw pozytywnych osobnej klasyfikacji, występującej w ich części równolegle do prawa pozytywnego ludzkiego. Było to prawo pozytywne boskie, nadane rodzajowi ludzkiemu trzy razy z osobna: bezpośrednio po stworzeniu człowieka, ponownie po odnowieniu rodzaju ludzkiego po potopie, a następnie w okresie odkupienia przez Chrystusa, zawartemu w Piśmie Świętym, które nadane były narodowi żydowskiemu jako wybranemu ${ }^{38}$, ale nakładającemu obowiązki na wszystkich ludzi od momentu, w którym zdolni byli oni je poznaćc ${ }^{39}$, a tym samym postrzeganego i ujmowanego przez Grocjusza w jego systematyce. Wyróżnia się ono, jak podkreślał, od prawa natury oraz prawa ludzkiego pozytywnego tym, że nie nakazuje i nie broni tego, co samo przez się z własnej istoty jest obowiązkowe lub niedozwolone, ale zabraniając powoduje, że czynność będzie niedozwolona, a jednocześnie nakazując sprawia, że będzie ona obowiązkowa ${ }^{40}$.

\footnotetext{
${ }^{37}$ Ius arctius patens $\&$ ab ipsa potestare civili non veniens, quanquam ei subditum, varium est, praecepta patria, dominica; \& si qua sunt similia in se continens. IBP, I, 1, 14.

${ }^{38}$ Ex omnibus populis unus est, cui peculiariter Deus iura dare dignatus est, populus scilicet Hebraeus. IBP, I, 1, 16.

${ }^{39} \mathrm{Hoc}$ autem aut datum est humano generi, aut populo uni. Humano generi ter ius datum a Deo reperimus: statim post hominem conditum, iterum in reparation humani generis post diluvium, postremo in sublimiori reparatione per Christum. Tria haec iura haud dubie omnes homines obligant, ex quo, quantum fatis est ad eorum notitiam pervenerunt. IBP, I, 1, 15; Ch. LINK, Herrschaftsordnung und bürgerliche Freiheit. Grenzen und Staatsgewalt in der älteren deutschen Staatslehre, Wien: Böhlau 1979, s. 232-234.

${ }^{40}$ Qua nota distat hoc ius non ab humano tantum iure, sed \& a divino volintario, quod non ea praecipit aut vetat, que per se ac suapte natura aut debita sunt aut illicit, sed vetando illicita, praecipiendo debita facit. IBP, I, 1,10.
} 


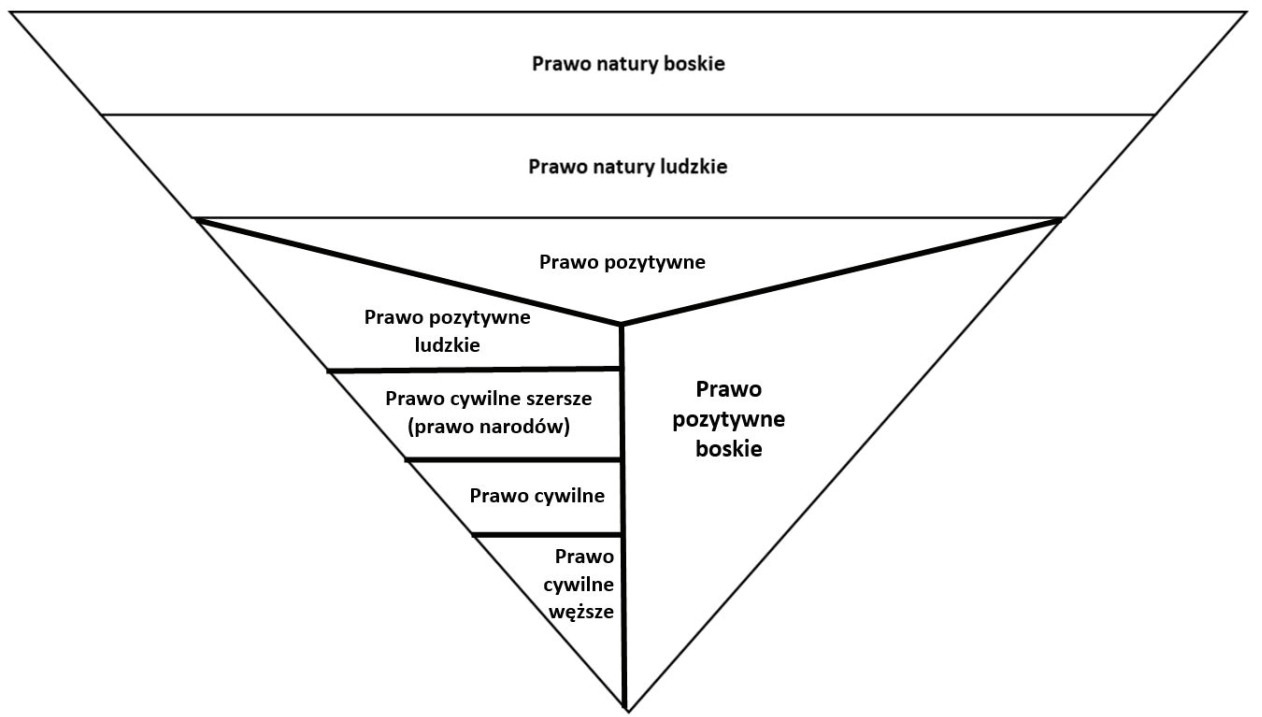

Nie ulega wątpliwości, że nauka Grocjusza odegrała w rozwoju nauki prawa szczególną rolę ${ }^{41}$, chociaż często uznaje się, że była jedynie stopniem czy też ogniwem w rozwoju między epokami ${ }^{42}$. Można przyjąć, że także współcześnie - czego się poniekąd nie spodziewano - wiele ze spostrzeżeń czy koncepcji Grocjusza dotyczących prawnie ujętych definicji, zwłaszcza odnoszących się do relacji społecznych, uznawanych często jeszcze niedawno za wsteczne, nabrało nieoczekiwanie na aktualności, co samo w sobie wydaje się warte głębszej refleksji. Ta jednak jej część, w której poprzez stworzenie systematyki prawa autor De iure belli ac pacis starał się nadać prawu, ale także rzeczywistości pewien porządek, wyrastała na bardzo szczególnym podejściu jej twórcy do tradycji ${ }^{43}$, do której w swoich poglądach wyraźnie

${ }^{41}$ R. Pound, Grotius in the Science of Law, “American Journal of International Law” 19 (1925) 4 , s. $685-688$.

${ }^{42}$ M. Scattola, Das Naturrecht vor dem Naturrecht. Zur Geschichte des ,,ius naturae” im 16. Jahrhundert, Tübingen: Max Niemeyer Verlag 1999, s. 217; J. ZAJADŁO, Hugo Grocjusz i hipoteza, s. 213.

${ }^{43}$ J. SAUTER, Die philosophischen Grundlagen des Naturrechts. Untersuchungen zur Geschichte des Rechts- und Staatslehre, Frankfurt/Main: Verlag Sauer und Auermann 1966 [unveränd. Aufl. Wien 1932]; A.-H. Chroust, Hugo Grotius and the Scholastic Natural Law Tradition, "The New Scholasticism. A Quaterly Review of Philosophy" 17 (1943), nr 2, s. 101-133; B. TIERNEY, The Idea of Natural Rights. Studies on Natural Rights, Natural Law and Church Law 1150-1625, Atlanta: Scholars Press 1997; J. FINNIS, Natural Law and Natural Rights, Oxford: Oxford Clarendon Press 1980; J.St. LegER, The "etiamsi daremus" of Hugo Grotius. Study in the Origins of International Law, Romae: Pontificum Athaeneum Internationale 1962; J. HervadA, The Old and the New in the Hypothesis "Etiamsi daremus" of Grotius, "Grotiana" 4 (1983), s. 3-20; L. BesselinK, 'The Impious 
się odwoływał, przede wszystkim zaś polegała, co należy podkreślić, na poszukiwaniu własnego konceptu prawa oraz jego systematyki. W tym kontekście pełniła ona funkcję pewnej konstrukcji prawa, ale zarazem instrumentu prawnego regulującego stosunki społeczne, chociaż sam Grocjusz, starając się zachować pewien porządek, podnosił wyraźnie, że w praktyce nie jest bynajmniej wskazane mieszanie praw cywilnych z prawami natury ${ }^{44}$. Konstruując swoją koncepcję systematyki prawa, okazywał się jednak myślicielem poszukującym jej teoretycznego ujęcia, które w epoce pewnego ideowego przełomu, mającego miejsce w XVI i XVII wieku, było próbą dania pewnej propozycji widzenia ładu prawnego niezbędnego, w jego rozumieniu, dla funkcjonowania społeczeństwa, a także źródeł podejścia Grocjusza do porządku prawnego ${ }^{45}$. Wskazywał przy tym wyraźnie na potrzebę i niezbędność prawa dla relacji społecznych, zwłaszcza na należytym oddzieleniu prawa stanowionego od naturalnego, o co nie zatroszczono się dotąd - jak podkreślał Grocjusz - w sposób wystarczający ${ }^{46}$. Budując swoją systematykę, był on poniekąd idealistą, wierzącym w moc prawa i jego skuteczność, które pomimo nadaniu stworzonej przez siebie systematyce określonej klasyfikacji, dawało oparcie jej w całości - co w gruncie rzeczy było w tym przypadku ówcześnie nadzwyczaj oryginalne - przede wszystkim na konceptach i zasadach. Te z kolei oparte były nie tylko na ujęciach normatywnych ${ }^{47}$, ale także - o czym niekiedy się nie pamięta - teologicznych ${ }^{48}$, co wyjaśniałoby istotę jego nauki o prawie.

Hypothesis Revisited', "Grotiana" 9 (1988), s. 3-63; R. FEENSTRA, Quelques remarques sur le sources utilisées par Grotius dans ses travaux de droit naturel, [w:] The World of Hugo Grotius (1583-1645): Proceedings of the International Colloquium Organized by the Grotius Committee of the Royal Netherlands Academy of Arts and Sciences, Rotterdam 6-9 April 1983, Amsterdam: Holland University Press 1984, s. 65-81.

${ }^{44}$ Hoc quoque omittendum non est, ne jura civilia cum naturali confundantur. IBP, II, 11.21.

${ }^{45}$ Ch. Hölzel, Grundlagen des Rechts - und Staatsdenkens bei Hugo Grotius, München 1970; P. OtTENWÄLDER, Zur Naturrechtslehre des Hugo Grotius, Tübingen: J. C. B. Mohr 1950; R. SCHNEPF, Naturrecht und Geschichte bei Hugo Grotius. Ein methodologischer Problem rechtsphilosophischer Begründung, „Zeitschrift für Neuere Rechtsgeschichte” 20 (1998), nr 1-2, s. 1-14; F. GRUNERT, Normbegründung und politische Legimität. Zur Rechts-und Staatsphilosophie der deutschen Frühaufklärung, Tübingen: Max Niemeyer Verlag 2000, s.77-108.

${ }^{46}$ Neque vero fieri potest, nisi, quod non fatis curatum est hactemus, ea quae ex constitution veniunt a naturalibus recte separentur. IBP, Prolog. 30.

${ }^{47}$ S. Strömholm, Grotius och den tidigare naturrätten, [w:] Den svenska juridikens uppblomstring i 1600-talets politiska, kulturella och religiösa stormaktssamhälle, red. G. Inger, Stockholm: A. B. Nordiska Bokhandeln 1984, s. 94-95.

${ }^{48}$ B. KNIEPER, Die Naturrechtslehre des Hugo Grotius als Einigungsprinzip der Christenheit, dargestellt an seiner Stellung zum Calvinismus, Frankfurt / Main: Johann-Wolfgang Universität zu Frankfurt am Main 1971. 


\section{BIBLIOGRAFIA}

BESSELINK Leonard: 'The Impious Hypothesis Revisited', “Grotiana” 9 (1988), s. 3-63.

CHroust Anton-Hermann: Hugo Grotius andtheScholastic Natural Law Tradition, "The New Scholasticism. A Quaterly Review of Philosophy” 17(1943), nr 2, s. 101-133.

EIKEMA Hommes Hendrik J. van: Naturrecht und positives Recht bei Johannes Althusius, [w:] Politische Theorie des Johannes Althusius, Hrsg. Karl-Wilhelm Dahm, Werner Krawietz, Dieter Wyduckel, Berlin: Duncker\& Humblot 1988, s. 371-390.

FEENSTRA Robert: Quelquesremarques sur le sources utilisées par Grotius danssestravaux de droit naturel, [w:] The world of Hugo Grotius (1583-1645), Proceedings of the International Colloquium Organized by the Grotius Committee of the Royal Netherlands Academy of Arts and Sciences, Rotterdam 6-9 April 1983, Amsterdam: Holland University Press 1984, s. 65-81.

FiNNIS John: Natural Law and Natural Rights, Oxford: Oxford Clarendon Press 1980.

GIERKE Otto: Johannes Althusius und die Entwicklung der naturrechtlichen Staatstheorien, Breslau: Verlag M. und H. Marens 1902.

GrotiUs Hugo: De iure belli ac pacis libri tres. In quibus ius naturae \& Gentium, item juris publici praecipua explicantur, Amsterdam 1646, Liber I, Caput 1.10.

GRUNERT Frank: Normbegründung und politische Legimität. Zur Rechts- und Staatsphilosophie der deutschen Frühaufklärung, Tübingen: Max Niemeyer Verlag 2000.

HaAKOnSSEN Knud: Natural Law and Moral Philosophy: From Grotius to the Scottish Enlightenment, Cambridge: Cambridge University Press 1996.

HAAKONSSEN Knud: The Moral Conservatism of Natural Rights, [w:] Natural Law and Civil Sovereignty. Moral Right and State Authority in Early Modern Political Thought, ed. Ian Hunter, David Saunders, Houndmills: Palgrave Macmillan 2002, s. 28-33.

HAGGenMaCher Paul: Genèse et signfication du koncept de ,iusgentium” chez Grotius“, "Grotiana” 2 (1981), s. 44-102, appendices s. 631-643.

Haggenmacher Paul: Droits subjectifs et systèmejuridique chez Grotius, [w:] Politique, droit et théologie chez Bodin, Grotius et Hobbes, Préface de Yves Charles Zarka, Paris: Éditions Kimé 1997, s. 73-78.

HeRvada Javier: The Old and the New in the Hypothesis "Etiamsidaremus" of Grotius, "Grotiana" 4 (1983), s. 3-20.

HOLTHÖFER Ernst: Die Literatur zum gemeinen und partikularen Recht in Italien, Frankreich, Spanien und Portugal, [w:] Handbuch der Quellen und Literatur der neueren europäischen Privatrechtsgeschichte, Bd. 2, Tlbd. 3, Hrsg. Helmut Coing, München: C.H. Beck 1977, s. 103-500.

HöLzEL Christian: Grundlagen des Rechts - und Staatsdenkens bei Hugo Grotius, München 1970

KNIEPER Barbara: Die Naturrechtslehre des Hugo Grotius als Einigungsprinzip der Christenheit, dargestellt an seiner Stellung zum Calvinismus, Frankfurt / Main: Johann-Wolfgang Universität zu Frankfurt am Main 1971.

LEGER James St.: The "etiamsidaremus" of Hugo Grotius. Study in the Origins of International Law, Romae: Pontificum Athaeneum Internationale 1962.

LINK Christoph: Herrschaftsordnung und bürgerliche Freiheit. Grenzen und Staatsgewalt in der älteren deutschen Staatslehre, Wien: Böhlau 1979.

OTTENWÄLDER Paul: Zur Naturrechtslehre des Hugo Grotius, Tübingen: J. C. B. Mohr 1950. 
Pound Roscoe: Grotius in the Science of Law, "American Journal of International Law" 19 (1925) 4, s. 685-688.

SAUTER Johannes: Die philosophischen Grundlagen des Naturrechts. Untersuchungen zur Geschichte des Rechts - und Staatslehre, Frankfurt/Main: Verlag Sauer und Auermann 1966 [unveränd. Aufl. Wien 1932].

SCATtOla Merio: Das Naturrecht vor dem Naturrecht. Zur Geschichte des „iusnaturae” im 16. Jahrhundert, Tübingen: Max Niemeyer Verlag 1999.

SCHNEPF Robert: Naturrecht und Geschichte bei Hugo Grotius. Ein methodologischer Problem rechtsphilosophischer Begründung, ,Zeitschrift für Neuere Rechtsgeschichte” 20 (1998), nr 1-2, s. 1-14.

SÖLLNER Alfred: Die Literatur zum gemeinen und partikularen Recht in Deutschland, Österreich, Niederlanden und der Schweiz, [w:] Handbuch der Quellen und Literaturder neueren europäischen Privatrechtsgeschichte, Bd. 2, Tlbd. 3, Hrsg. Helmut Coing, München: C.H. Beck 1977, s. 501-614.

STRÖMHOLM Stig: Grotius och den tidigarenaturrätten, [w:] Den svenskajuridikensuppblomstring i 1600-talets politiska, kulturella och religiösastormaktssamhälle, red. Göran Inger, Stockholm: A.B. NordiskaBokhandeln 1984, s. 94-95.

TIERNEY B.: The Idea of Natural Rights. Studies on Natural Rights, Natural Law and Church Law 1150-1625, Atlanta: Scholars Press 1997;

Tuck Richard: Grotius, Carneades and Hobbes, "Grotiana" 4 (1983), s. 43-62.

TUCK Richard: Philosophy and Government 1572-1651, Cambridge: Cambridge University Press 1993.

WIEACKER Franz: Privatrechtsgeschichte der Neuzeit unter besonderer Berücksichtigung der deutschen Entwicklung, Göttingen: Vandenhoeck\& Ruprecht 1952.

WINTERS Paul J.: Die „Politik“ des Johannes Althusius und ihre zeitgenössischen Quellen. Zur Grundlegung der politischen Wissenschaft im 16. und im beginnenden 17. Jahrhundert, Freiburg im Breisgau: Verlag Rombach 1963.

ZAJADŁo Jerzy: Hugo Grocjusz i hipoteza etiamsi daremus, non esse Deum, „Czasopismo Prawno-Historyczne" 58 (2006), z. 1, s. 208-209.

\section{GROCJUSZOWSKA SYSTEMATYKA PRAWA}

Streszczenie

Przedmiotem artykułu jest odtworzenie koncepcji prawa przedstawionej w nauce Hugo Grocjusza (1583-1545), zawartej w jego głównym dziele Ius belli ac pacis libri tres (1625). Koncepcja prawa Grocjusza mająca swoją systematykę, nie była jednak oparta na ujęciach normatywnych bądź zestawieniach przepisów prawa, służących praktyce jurydycznej czy też dydaktyce; była natomiast konstrukcją wynikającą z przesłanek ideowych, zawierającą zasady i reguły prawne stanowiące wyraz filozoficznego i teleologicznego podejścia Grocjusza do prawa. Systematyka prawa Grocjusza, zbudowana na hierarchicznym porządku praw, występujących w poziomach od najwyżej ustanowionego i najszerszego zasięgiem prawa natury do rozbudowanego prawa pozytywnego, miała jednak w rozumieniu Grocjusza także znaczenie praktyczne. Była ona bowiem konstrukcją istniejącego i funkcjonującego w stosunkach społecznych ładu prawnego, stanowiącego istotny element świadomości ludzi stosujących się do niego. W takim też podejściu do prawa i porządku prawnego Grocjusz upatrywał zasadnicze przeznaczenie swojego przedsięwzięcia.

Słowa kluczowe: Hugo Grocjusz; koncepcja prawa; system prawa; prawo natury; prawo pozytywne 


\section{GROTIUS LAW SYSTEMATICS}

\section{S u m m a ry}

The subject of this article is rendering of law conception presented in Hugo Grotius (1583-1545) learning enclosed in his main work Ius belli ac pacis libri tres (1625). The Grotius law conception that have been had its own systematics was based however not on normative settlements or statements of law regulations serving in juridical practice and also didactics whereas it was construction of law resulting of ideological premises containing law principles and rules being the express of philosophical and theological approach of Grotius to law. Grotius law systematics built on hierarchic order of laws existed on the levels of law from the highest placed and having widest extent law of nature to expanded and differentiated positive law had still also in Grotius understanding a practical meaning. It was a construction of law order existing and functioning in social relations reflecting a certain natural order being an essential element consciousness of men adhering to it. In this approach to law and law order Grotius has been seen the fundamental purpose of his intention.

Key words: Hugo Grocjusz; conception of law; system of law; law of nature; positive law 